\title{
First record of Carychium minimum Müller, 1774 in New Brunswick, Canada (Mollusca: Gastropoda: Ellobioidea)
}

\author{
Robert G. Forsyth \\ Research Associate, New Brunswick Museum, 277 Douglas Avenue, Saint John New Brunswick, Canada E2K 1E5 \\ E-mail: rforsyth@mollus.ca
}

\begin{abstract}
The minute land snail, Carychium minimum Müller, 1774 is reported from New Brunswick, Canada. This new record further adds additional data to support the supposition that this introduced, European species is probably more widespread over temperate North America than currently known.
\end{abstract}

Keywords: introduced species, Atlantic Canada, Pulmonata, Ellobiidae

The terrestrial snail genus Carychium Müller, 1774, is a relatively small group of microsnails belonging to the family Ellobiidae or Carychiidae within the superfamily Ellobioidea (Bouchet et al. 2005; Martins 2007; Weigand et al. 2013) that in North America is known by just eight native and two introduced species (Pilsbry 1948; Turgeon et al. 1998). Carychium minimum Müller, 1774 (Figure 1) is native over much of Europe and parts of western Asia (Egorov 2007; Welter-Schultes 2012), and is introduced to North America where it was first reported over 100 years ago (Clapp 1912). Recently, C. minimum has been included in molecular studies to understand speciation and patterns of distribution (e.g., Weigand et al. 2012, 2013), and on a more basic level, new records of have been found that extend ranges and fill gaps (Forsyth 2004; Forsyth et al. 2008; Grimm et al. 2010; Weigand and Jochum 2010; Pearce and Payne 2011; Holm 2014). Some populations are known to be well established and fully naturalized and Weigand and Jochum (2010) have suggested that C. minimum could be more widespread and naturalized throughout northeastern North America.

This paper reports the first record of C. minimum (Figure 1) from the province of New Brunswick, Canada, as well as the first record from Atlantic Canada, and further supports the probability that this species is more widespread than known over temperate North America.

On 18 August 2014, as part of the "bioblitz" of the Grand Lake Protected Natural Area and nearby areas in central New Brunswick, Canada, 16 live specimens of Carychium minimum (Figure 1) were collected by R. G. Forsyth from the end of Longs Creek Road, on the shore of Mactaquac Lake, a widening of the Saint John River, upstream from Fredericton ( $45^{\circ} 52^{\prime} 06.5^{\prime \prime} \mathrm{N}$, $055^{\circ} 44^{\prime} 44.6^{\prime \prime} \mathrm{W}$; datum WGS84; Figure 2). Specimens were picked by hand from debris from along the shore of the lake.
The end of the road had been widened by fill composed of broken rock, which facilitates a boat launch and room for turning and parking vehicles. Among this broken rock fill were a diverse assemblage of common roadside weeds, including Woodland Angelica, Angelica sylvestris L. Wave-borne driftwood and smaller driftwood fragments were washed up into the rocks. Several species of small terrestrial snails and slugs were collected from the moist undersurfaces of this drift material. Specimens of all species were deposited in the New Brunswick Museum (NBM) mollusc collection; C. minimum were accessioned in the mollusc collection under the number NBM 008905. Identification of this species were facilitated by consulting primarily the publications of Kerney and Cameron (1979), Burch and Van Devender (1980) and Cameron (2003).

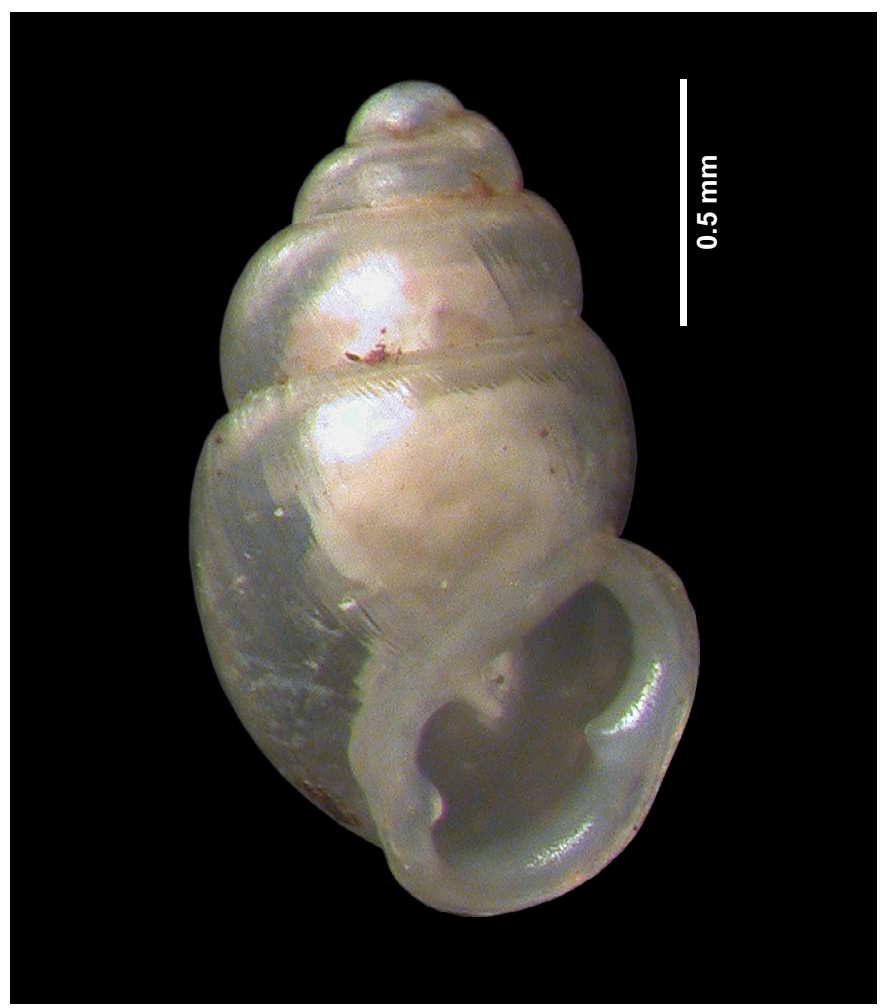

Figure 1. Carychium minimum, end of Longs Creek Road, on the shore of Mactaquac Lake, Saint John River, New Brunswick, Canada (4552'06.5" N, $066^{\circ} 55^{\prime} 44.6^{\prime \prime}$ ), leg. R. G. Forsyth, 18 August 2014, length (maximum dimension of shell), $1.7 \mathrm{~mm}$ (NBM 008905). 


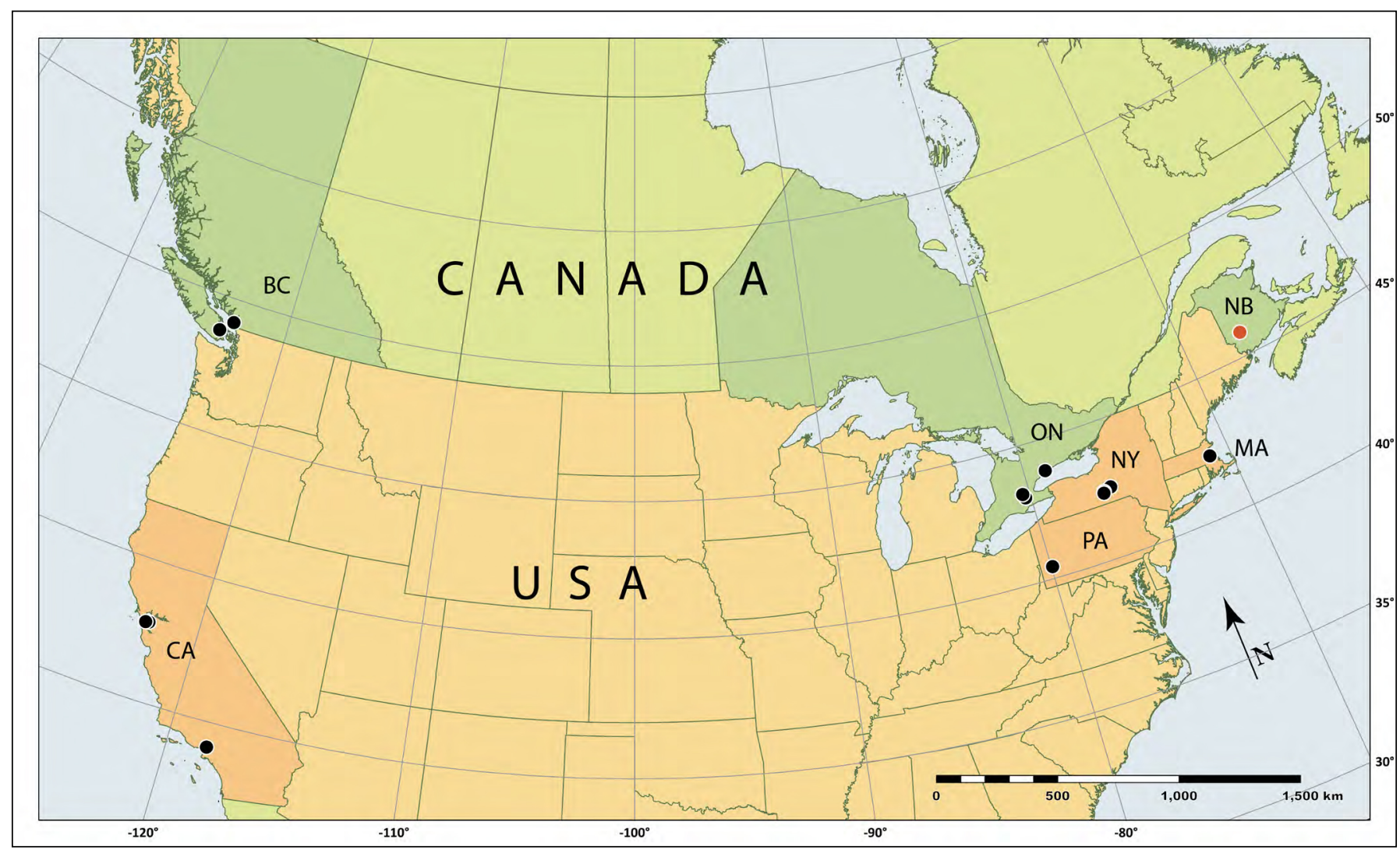

Figure 2. Records of Carychium minimum in Canada and the United States. Black circles: Previous records from literature and collections (see Table 1). Red circle: The new record from New Brunswick. Provincial/state abbreviations: BC, British Columbia; CA, California; MA, Massachusetts; NB, New Brunswick; NY, New York; ON, Ontario; PA, Pennsylvania.

Other species of molluscs found at the same site were Arion sp. [likely A. fuscus (Müller, 1774)], Deroceras laeve (Müller, 1774), Oxychilus sp., Oxyloma sp., Trochulus sp. [likely T. hispidus (Linnaeus, 1758)], Vallonia costata (Müller, 1774), and Zonitoides nitidus (Müller, 1774).

The shell of Carychium minimum is minute (length/maximum dimension: $1.9 \mathrm{~mm}$ ), colourless or translucent white, and with fine, low colabral rib-striae. The aperture has a welldeveloped columellar lamella that projects into the aperture and spirals up inside the last whorl. The outer lip when mature is thickened with a blunt bulging callus-like "tooth". Fullgrown shells have four whorls, as counted by the method of Cameron (2003). New Brunswick specimens fit these characters, although it is difficult to see the internal lamella because specimens were alive when collected. Of the 16 specimens collected, 6 where immature; the shells of the remaining 10 specimens measured 1.7-1.85 long (mean: $1.7 \mathrm{~mm}$; standard deviation: o.088) and all had four whorls.

Among the three native Carychium spp. in the northeastern U.S. and eastern Canada (Pilsbry 1948; Burch and Van Devender 1980; Weigand and Jochum 2010). C. minimum is most similar to C. exiguum (Say, 1822). However, shells of the latter differ by the greater number of whorls (five rather than four), are smoother with little evidence of colabral rib-striae, and have the palatal denticle less prominent. The other two native species (C. exile H.C. Lea, 1842 and C. nannodes Clapp, 1905) are much narrower than C. minimum and are unlikely to be confused with it. All three of the native species are expected from natural woodland habitats, unlike the New Brunswick site for C. minimum.
Carychium minimum is more likely to be confused with its European congener, C. tridentatum (Risso, 1826), which is slightly more slender, has one additional whorl when mature, and within the last whorl, the lamella is not smoothly curved around the columella but rather, makes angled curves (Cameron 2003).

Until recently, Carychium minimum was little-known in North America. Clapp (1912) found it in a greenhouse in Quincy, Massachusetts, USA, which Winslow (1922) later figured. Roth (1982) believed that Clapp's record was instead C. tridentatum, a species that has recently been found in British Columbia, Canada (Forsyth and Williston 2012). However, there is some disagreement as to the identity of the Massachusetts population; Pearce and Payne (2011) identified the species as C. minimum. With regards to whorl count, Winslow's figure of a Massachusetts shell [republished in Burch and Van Devender (1980)] suggests that $C$. minimum is correct.

Since its initial discovery in North America more than a century ago, Carychium minimum is reported in the literature from two Canadian provinces and four U.S. states (Table 1). The new record of Carychium minimum from New Brunswick adds to the growing list of provinces and states where this species is known to occur. All known sites $(n=14)$, including the contested record from Massachusetts, are mapped (Figure 2).

Carychium minimum has been characterized as nearly amphibious and lives in wet, periodically inundated habitats, where it is capable of surviving prolonged floods (Kerney 1999). Some of the records (Ontario and Courtland County, New York) are based on dead shells found in stream debris. These suggest an association, seen elsewhere, with streamside 
habitats but can also infer a means of passive dispersal of living snails. The new record from New Brunswick, occupying the shore of a large river, shares this habitat feature with the population in Richmond at the delta of the Fraser River, British Columbia (Holm 2014; Holm pers. comm.). Other records (Massachusetts and Vancouver Island, British Columbia) were from a greenhouse and an outdoor, but artificially watered, retail plant nursery. At the Vancouver Island site, snails were found on the bottoms of potted plants, which may suggest that the trade in nursery stock could be a vector for dispersal of $C$. minimum.

Carychium minimum should be expected elsewhere within New Brunswick, and almost certainly at other places along the shore of the Saint John River, the largest river in the province. Outside of New Brunswick, it may be expected elsewhere in Atlantic Canada and probably also southern Quebec, given that it occurs in southern Ontario. Weigand and Jochum (2010) had earlier suggested that $C$. minimum might be more widespread in northeastern North America than previously thought; the new record from New Brunswick adds further evidence that this may be true.

\section{ACKNOWLEDGMENTS}

This paper resulted from fieldwork conducted during the second year of the 2013-2014 New Brunswick Museum bioblitz at the Grand Lake Protected Natural Area. I thank the New Brunswick Museum (Saint John), and in particular, Dr. Donald McAlpine and Mary Sollows for supporting this research. I also thank George P. Holm (Richmond, British Columbia) for generously showing me the Fraser River population of Carychium minimum and Frederick W. Schueler (Bishops Mills, Ontario) for sharing his data and specimens. Funding in support of 2014 NBM Bioblitz was provided to DFM by the New Brunswick Environmental Trust Fund, New Brunswick Wildlife Trust Fund, Environment Canada, University of New Brunswick Grand Lake Meadows Endowment Fund, New Brunswick Department of Natural Resources, J.D. Irving Ltd. and Stantec Consulting Ltd.

\section{LITERATURE CITED}

Bouchet, P., J. Frýda, B. Hausdorf, W. Ponder, Á. Valdés and A. Warén. 2005. Working classification of the Gastropoda; pp. 240-284, in: Bouchet, P. and J.-P. Rocroi (eds.). Classification and nomenclator of gastropod families. Malacologia 47(1). (http:// biodiversitylibrary.org/page/25127402).

Burch J.B. and A.S. Van Devender. 1980. Identification of eastern North American land snails: The Prosobranchia, Opisthobranchia and Pulmonata (Actophila). Walkerana 1(2): 33-80 (http:// molluskconservation.org/WALKERANA/Vol1/walkerana\%20 vol1\%20no2\%2033-80.PDF).

Cameron, R.A.D. 2003. Key for the identification of land snails in the British Isles. Field Studies Council, Occasional Publication 79: iv $+82 \mathrm{pp}$.

Clapp, W.F. 1912. Carychium minimum Mull. The Nautilus 26(1): 24 (http://biodiversitylibrary.org/page/1738223).

Egorov, R. 2007. Ellobioidei. Cassidulidae, Leucophytiidae, Carychiidae. Treasure of Russian Shells 8: 33 pp.

Forsyth, R.G. 2004. Land Snails of British Columbia (Royal BC Museum Handbook). Victoria: Royal British Columbia Museum. 188 + [8] pp.

Forsyth, R.G. and P. Williston. 2012. Terrestrial snails from an urban park in Vancouver, British Columbia. The Festivus 44(7): 77-80.

Forsyth, R.G., M.J. Oldham and F.W. Schueler. 2008. Mollusca,
Table 1. Known occurrences of Carychium minimum in North America (mapped in Figure 2).

\begin{tabular}{|c|c|c|}
\hline $\begin{array}{l}\text { Country, } \\
\text { province/state }\end{array}$ & Locality & Source \\
\hline \multicolumn{3}{|l|}{ Canada } \\
\hline \multirow[t]{2}{*}{ British Columbia } & Cobble Hill, Vancouver Island & Forsyth (2004) \\
\hline & Richmond, Fraser River & Holm (2014) \\
\hline New Brunswick & Saint John River & New record \\
\hline \multirow[t]{2}{*}{ Ontario } & Grand River ( 2 sites) & Forsyth et al. (2008) \\
\hline & Whitby & Unpublished data \\
\hline \multicolumn{3}{|l|}{ United States } \\
\hline \multirow[t]{3}{*}{ California } & San Francisco & Roth (1982) \\
\hline & Oakland & Roth (1982) \\
\hline & Los Angeles & Holm (2014) \\
\hline Massachusetts & Quincy & Clapp (1912) \\
\hline \multirow[t]{2}{*}{ New York } & Ithaca (2 sites) & $\begin{array}{l}\text { Weigand and Jochum } \\
\text { (2010) }\end{array}$ \\
\hline & $\begin{array}{l}\text { Tioughnioga River, Courtland } \\
\text { County }\end{array}$ & Grimm et al. (2010) \\
\hline Pennsylvania & Pitsburgh & Pearce and Payne (2011) \\
\hline
\end{tabular}

Gastropoda, Ellobiidae, Carychium minimum, and Ferussaciidae, Cecilioides acicula: Distribution extension and first provincial records of two introduced land snails in Ontario, Canada. Check List 4(4): 449-452 (http://www.checklist.org.br/getpdf? NGD141-08).

Grimm, F.W., R.G. Forsyth, F.W. Schueler and A. Karstad. "2009" [2010]. Identifying Land Snails and Slugs in Canada: Introduced Species and Native Genera. Ottawa: Canadian Food Inspection Agency. iv +168 pp.

Holm, G. 2014. An unexpected find of Carychium minimum Müller, 1774, an uncommon introduced land snail. The Dredgings 54(1): 3-4.

Kerney, M.P. 1999. Atlas of the Land and Freshwater Molluscs of Britain and Ireland. Colchester, UK: Harley Books. 264 pp.

Kerney, M.P. and R.A.D. Cameron. 1979. A field Guide to the Land Snails of Britain and North-west Europe. London: Collins. 288 pp., $24 \mathrm{pl}$.

Martins, A.M. de F. 2007. Morphological and anatomical diversity within the Ellobiidae (Gastropoda, Pulmonata, Archaeopulmonata). Vita Malacologica 4: 1-28.

Pearce, T.A. and S.L. Payne. 2011. European Carychium land snails in Pennsylvania. Tentacle 19: 13 (http://www.hawaii.edu/cowielab/ tentacle/Tentacle_19.pdf).

Pilsbry, H.A. 1948. Land Mollusca of North America (north of Mexico). Volume 2, Part 2. The Academy of Natural Sciences of Philadelphia, Monographs 3: i-xlvii + 521-1113.

Roth, B. 1982. European land mollusks in the San Francisco Bay area, California: Carychium minimum Müller and the Arion hortensis complex. The Veliger 24(4): 342-344 (http://biodiversitylibrary. org/page/42408599).

Turgeon, D.D., J.F. Quinn, A.E. Bogan, E.V. Coan, F.G. Hochberg, W.G. Lyons, P.M. Mikkelsen, R.J. Neves, C.F.E. Roper, G. Rosenberg, B. Roth, A. Scheltema, F.G. Thompson, M. Vecchione and J.D. Williams. 1998. Common and scientific names of aquatic invertebrates from the United States and Canada: Mollusks. $2^{\text {nd }}$ edition. American Fisheries Society Special Publication 26: $\mathrm{x}+526 \mathrm{pp}$.

Weigand, A.M. and A. Jochum. 2010. Mollusca, Gastropoda, Ellobioidea, Carychium minimum O.F. Müller, 1774: Filling gaps. New population record for the State of New York, northeastern United States. Check List 6(4): 517-518 (http://www.checklist. org.br/getpdf?NGDo84-10).

Weigand, A.M., M. Pfenninger, A. Jochum and A. Klussmann-Kolb. 2012. Alpine crossroads or origin of genetic diversity? Comparative phylogeography of two sympatric microgastropod species. PLoS 
ONE 7(5): e37089 (doi: 10.1371/journal.pone.0037089).

Weigand, A.M., A. Jochum, R. Slapnik, J. Schnitzler, E. Zarza and A. Klussmann-Kolb. 2013. Evolution of microgastropods (Ellobioidea, Carychiidae): Integrated taxonomic, phylogenetic and evolutionary hypotheses. BMC Evolutionary Biology 13: 18 (doi: 10.1186/1471-2148-13-18).

Welter-Schultes, F.W. 2012. European Non-marine Molluscs, a Guide for Species Identification. Göttingen, Germany: Planet Poster
Editions. $679+[78]$ pp.

Winslow, M.L. 1922. Notes on the internal lamellae of Carychium. Occasional Papers of the Museum of Zoology, University of Michigan 128: 17 pp. (http://hdl.handle.net/2027.42/56567).

Received: October 2014

Accepted: December 2014

Editorial responsibility: Luis E. Arruda Bezerra 